\title{
COPYRIGHT $^{\circledR} 2020$ EDIZIONI MINERVA MEDICA
}

\section{SARS-CoV-2 and COVID-19: facing the pandemic together as citizens and cardiovascular practitioners}

\author{
Giuseppe BIONDI ZOCCAI 1,2 *, Giovanni LANDONI 3,4, Roberto CARNEVALE 1,2, \\ Elena CAVARRETTA 1,2, Sebastiano SCIARRETTA 1, 5, Giacomo FRATI 1,5
}

\begin{abstract}
Department of Medico-Surgical Sciences and Biotechnologies, Sapienza University, Latina, Italy; ${ }^{2}$ Mediterranea Cardio Center, Naples, Italy; ${ }^{3}$ Department of Anesthesia and Intensive Care, IRCCS San Raffaele Scientific Institute, Milan, Italy; ${ }^{4}$ Faculty of Medicine, Vita-Salute San Raffaele University, Milan, Italy; 5 IRCCS NEUROMED, ozzilli, Isernia, Italy

Corresponding author: Giuseppe Biondi Zoccai, Department of Medico-Surgical Sciences and Biotechnologies, Sapienza Univerty, Corso della Repubblica 79, 04100 Latina, Italy. E-mail: giuseppe.biondizoccai@uniroma1.it
\end{abstract}

Uneasy lies the head that wears a crown William Shakespeare espite their highbrow name, coronarvirus have proved eminently disruptive in recent years. ${ }^{1,2}$ Since the epidemic of severe respiratory distress syndrome (SARS) due to the SARS-related coronavirus (SARS-CoV) infection and the Middle East respiratory syndrome (MERS) due to the MERS-related coronavirus (MERS-CoV), several experts could expect the advent of additional epidemics due to coronaviruses. ${ }^{3,} 4$ Yet, the ongoing pandemic of coronavirus-associated disease 2019 (COVID-2019) due to the infection from SARSCoV-2 (also known as 2019-nCoV) has wreaked havoc worldwide (Figure 1). ${ }^{5,6}$ As Italian citizens and cardiovascular practitioners, we are now facing this storm, with a mix of incredulity, fear, boldness, and sense of duty. ${ }^{7-9}$ In addition, our unique editorial privileges urge us to summarize poignant facts on this global emergency, and provide some important insights for patients, practitioners, decision-makers, and researchers. An important preamble to all the following discussed issues is the fact that information is accruing rapidly and some facts which may be considered correct and valid today may sooner or later be proved incomplete or incorrect. ${ }^{10,11}$ Yet, we can clarify some known, unknown, and ensuing implications (Table I).

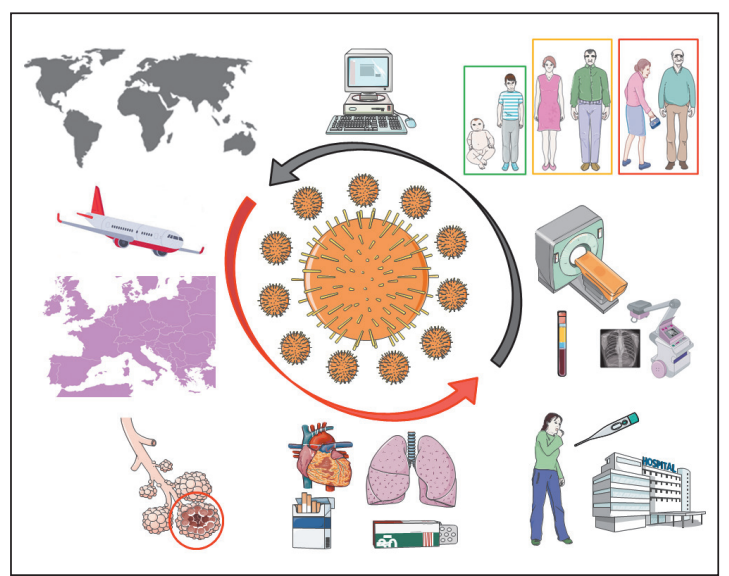

Figure 1.-Challenges of coronavirus-associated disease 2019 (COVID-2019). Local infection cases of severe respiratory distress syndrome-related coronavirus (SARS$\mathrm{CoV}-2$ ) in a globalized world lead to global pandemic. After contagion, several risk factors may impact on patient risk of symptomatic and/or severe disease, with COVID-2019 typically beginning with fever, cough and dyspnea, with radiologic signs of pulmonary involvement. Eventually, patient age and comorbidities mostly impact on prognosis and response to invasive mechanical ventilation, if needed. Data science, big data, social media and other novel communication and analysis tools may help adopting effective population measures and also streamline research efforts.

First, SARS-Cov-2 is a Betacoronavirus probably originating in chrysanthemum bats, with pangolins as intermediate hosts. ${ }^{5}$ It is characterized by glycosylated spike proteins which have high 


\section{COPYRIGHT $^{\circledR} 2020$ EDIZIONI MINERVA MEDICA}

TABLE I.-Current known and unkown facts on coronavirus-associated disease 2019 (COVID-19), including implications for cardiovascular practitioners.

\begin{tabular}{|c|c|c|c|}
\hline Dimensions & Known & Unknow & Cardiovascular implications \\
\hline Biology & $\begin{array}{l}\text { COVID-19 is caused by SARS- } \\
\text { Cov- } 2 \text { a betacoronavirus } \\
\text { which was first identified in } \\
\text { late } 2019 \text { in China }\end{array}$ & $\begin{array}{l}\text { Mode of transmission to humans } \\
\text { from bats or other species is } \\
\text { unclear }\end{array}$ & $\begin{array}{l}\text { SARS-Cov-2 may directly impact on } \\
\text { cardiovascular function, directly replicating } \\
\text { and injury cells and tissues; indirect injury is } \\
\text { also likely }\end{array}$ \\
\hline Epidemiology & $\begin{array}{l}\text { Highly contagious, incubation } \\
\text { up to } 24 \text { days, latency up to } \\
10 \text { days }\end{array}$ & $\begin{array}{l}\text { The real extent of contagion remains } \\
\text { unclear, but likely vast portions of } \\
\text { untested populations are already } \\
\text { infected and contagious }\end{array}$ & $\begin{array}{l}\text { It is unclear whether SARS-CoV-2 infection has } \\
\text { epidemiologic specificities in patients with or } \\
\text { at risk of cardiovascular disease (e.g. those } \\
\text { with atherothrombosis) }\end{array}$ \\
\hline Diagnosis & $\begin{array}{l}\text { Dedicated RT-PCR test available } \\
\text { but expensive and not with } \\
\text { immediate results; Chest } \\
\text { CT has a high sensitivity in } \\
\text { epidemic areas; differential } \\
\text { diagnosis with other } \\
\text { cardiopulmonary conditions } \\
\text { (e.g. AHF, PTE) }\end{array}$ & $\begin{array}{l}\text { Point of care tests have limited } \\
\text { precision and timeliness, and it } \\
\text { is unclear whether routine quasi- } \\
\text { universal testing will be able to } \\
\text { correctly identify infected people } \\
\text { given incubation features }\end{array}$ & $\begin{array}{l}\text { Diagnosis of COVID-19 may be complicated } \\
\text { in patients with pre-existing cardiopulmonary } \\
\text { disease, and the opposite is also true; other } \\
\text { infectious and inflammatory conditions should } \\
\text { not be disregarded as well, especially if SARS- } \\
\text { CoV-2 positivity turns out to be very prevalent }\end{array}$ \\
\hline Prognosis & $\begin{array}{l}\text { Case fatality } 1-5 \% \text { or lower, } \\
\text { several prognostic risk } \\
\text { factors, ranging from age, } \\
\text { smoking, elevated ESR, CRP, } \\
\text { LDH, and chest CT features } \\
\text { (opacifications, consolidations, } \\
\text { thickening) }\end{array}$ & $\begin{array}{l}\text { Precise and timely risk- } \\
\text { prognostication is not possible } \\
\text { yet, nor is accurate appraisal of } \\
\text { real case fatality including in the } \\
\text { denominator all those infected but } \\
\text { still asymptomatic }\end{array}$ & $\begin{array}{l}\text { Each individual and each patient under } \\
\text { cardiovascular care may be already infected } \\
\text { with SARS-CoV-2 or be at risk of being } \\
\text { infected by healthcare personnel or other } \\
\text { people }\end{array}$ \\
\hline Management & $\begin{array}{l}\text { Supportive care, ranging } \\
\text { from oxygen to mechanical } \\
\text { ventilation and ECMO is } \\
\text { beneficial in helping the } \\
\text { patient clear the virus }\end{array}$ & $\begin{array}{l}\text { Unclear role for ACEi/ARB in } \\
\text { preventing or promoting infection; } \\
\text { unclear role for remdesivir, } \\
\text { lopinavir/ritonavir, interferon- } \\
1 \beta \text {, chloroquine phosphate, } \\
\text { intravenous immunoglobulin, } \\
\text { MoAB or vaccines (if and when } \\
\text { available) }\end{array}$ & $\begin{array}{l}\text { Supportive care may by itself be associated } \\
\text { with cardiac strain/injury; cardiovascular } \\
\text { medications (e.g. anticoagulants) may interfere } \\
\text { with supportive care; conflicting evidence } \\
\text { for ACEi/ARB in preventing or promoting } \\
\text { infection (recommendation is to maintain } \\
\text { current therapy awaiting for additional studies) }\end{array}$ \\
\hline
\end{tabular}

ACEi: angiotensin converting enzyme inhibitors; AHF: acute heart failure; ARB: angiotensin receptor blockers; CRP: C-reactive protein; CT: computed tomography; ECMO: extracorporeal membrane oxygenation; ESR: erythrocyte sedimentation rate; LDH: lactate dehydrogenase; MoAB: monoclonal antibodies; PTE: pulmonary thromboembolism; RT-PCR: reverse-transcription polymerase chain reaction.

binding capacity toward angiotensin-converting enzyme 2 (ACE2) and employs the cellular transmembrane protease, serine 2 (TMPRSS2) for $\mathrm{S}$ protein priming expressed by lung cells. ${ }^{12,13}$

It has spread initially in the Chinese city of Wuhan, Hubei province, being recognized first in December 2019, when forceful regional containment was exercised. ${ }^{14}$ Despite this, after weeks, COVID-19 cases were reported in several countries, and to date asymptomatic cases, symptomatic cases, deaths, and healed cases are reported in most countries worldwide. The virus is abundant in infected people (with almost a billion RNA copies per $\mathrm{mL}$ of sputum), and can resist on contaminated objects for several hours or even days (including air exhaust outlets). ${ }^{15}$ It has a moderate incubation period (which can last up to 20-24 days though), with a reproductive number $\left(\mathrm{R}_{0}\right)$ greater than 2.5 . Most infections are likely asymptomatic, and this leads to the potential of asymptomatic carriers. ${ }^{16}$ Yet, symptomatic infections are relatively common, with a median patient age of 50-60 years, and range from cold-like symptoms, to cough, sore throat, fever, fatigue, myalgias, pneumonia, acute respiratory distress syndrome (ARDS), multi-organ failure (MOF) and death. Worsening with dyspnea or other severe features typically occurs between 5 and 10 days after initial symptom onset. ${ }^{17}$ Intriguingly, substantial variability and temporal differences between countries may be largely explained by numbers of diagnostic tests performed, pollution, and crowding, rather than on other factors, thus suggesting that most countries worldwide will face this substantial emergency. ${ }^{18}$

In terms of diagnosis, patients with moderate or severe symptoms typically display low lymphocyte counts, but high markers of systemic inflammation, whereas features of atypical pneumonia are evident at chest X-rays and chest computed 


\section{COPYRIGHT $^{\odot} 2020$ EDIZIONI MINERVA MEDICA}

SARS-COV-2, COVID-19 AND CV SPECIALISTS

BIONDI ZOCCAI

tomography (CT), with frequent ground-glass infiltrates in the latter. ${ }^{19}$ Risk-prognostication is difficult with COVID-19, as case fatality rate is heavily influenced by inaccuracies in measuring asymptomatic infections, with a median age of deceased patients of 70-80 years. ${ }^{19,} 20$ Indeed, since it is almost impossible to track the real number of infected subjects in the population, based on the fact that most of them have no or very few symptoms, it is very unlikely that we are able now to understand the real mortality rate of COVID-19: we may indeed state that lack of evidence of transmission and disease is not evidence of lack of transmission and disease. Yet, it seems that mortality ranges between $1 \%$ and $5 \%$ among symptomatic patients (with higher rates however in the very elderly). Of note, although the mortality rate of SARS was significantly higher, both contagiousness and focus on frail of COVID-19 make the overall death toll associated with this disease higher than that of SARS. ${ }^{14}$

Children appear completely spared by severe or fatal disease, whereas this may occur in adult patients of any age, even young and fit ones. Yet, most reports have shown that there is a clearly higher risk of severe infection (requiring non-invasive ventilation, invasive ventilation, vasopressors, extra-corporeal membrane oxygenation) or death in the elderly, those with one or more comorbidity, or even those with one or more cardiovascular risk factor (e.g. smoking history, hypertension, obesity, diabetes mellitus).17, 19, 21 Notably, even apparently mild infections may lead to hospital admission and even ARDS later on. 19, 21 Early reports from the Italian Istituto Superiore di Sanità (ISS) on as many as 155 Italian fatal cases of COVID-19 confirm the above findings. ${ }^{22}$ In particular, fever and dyspnea were very common, but cough, diarrhea and hemoptisis were also present occasionally. Median age of such cases was 81 years, with $69 \%$ men, and frequent comorbidities, including cardiovascular conditions such as hypertension and ischemic heart disease. Management to date is mainly supportive, similar to that of other infections causing atypical pneumonia, shock or MOF, with supportive care, oxygen supplementation, and the measures specified previously. Anecdotal reports on the potential usefulness of acyclovir, remdesivir, lopinavir/ ritonavir, interferon-1 $\beta$, chloroquine phosphate, anakinra, baricitinib, ruxolitinib, fedratinib and intravenous immunoglobulin appear promising but controlled trials are needed before considering them on a large scale. ${ }^{23-25}$ Similarly, no vaccines are yet available, and several months will be needed to refine an effective and safe one. ${ }^{1}$

From a cardiovascular perspective, as physicians we need to ensure we minimize our risk of contagion, and at the same time minimize the risk of transmitting the disease to other colleagues and patients. ${ }^{26}$ In addition, we must be aware that, given its increasing prevalence, COVID-19 enters the differential diagnosis of most cases of chest pain, dyspnea at rest, acute heart failure, arrhythmias, and non-ST-elevation myocardial infarction. Indeed, SARS-CoV-2 has been found in cardiomyocytes in many series, it may cause myocarditis and myocardial injury, with ECG changes, sustained arrhythmias, left ventricular systolic dysfunction, and increase in troponins, and other markers of myocardial necrosis. In addition, COVID-19 may resemble pulmonary thromboembolism and differential diagnostic clues need to be carefully sought. Therefore, we really need novel biomarkers to rapidly discriminate COVID-19 from the above-mentioned cardiovascular diseases. Moreover, hypoxemia is likely to lead to secondary myocardial injury, as is the typical proinflammatory milieu of ARDS and MOF. Finally, treatments used for severe COVID-19, including chloroquine, vasopressors and mechanical ventilation, may also impact unfavorably on cardiac function.

In conclusion, we hope the present piece of information will prove useful to inform concisely yet validly cardiovascular practitioners facing the SARS-CoV-2 pandemic. While containment and mitigation will benefit at large the management of this emergency, and we need to comply duly to such measures as citizens, ${ }^{27}$ as practitioners we will need to proactively diagnose, riskstratify and manage patients with COVID-19, while not disregarding all other important cardiovascular conditions, which may well be neglected or worsened by this infectious disease. The hypothesis that inadequate management of this pandemic could lead to $60 \%$ of Italians being infected and as many as 1 million deaths should 


\section{COPYRIGHT $^{\circledR} 2020$ EDIZIONI MINERVA MEDICA}

not scare us or push people toward negation, ${ }^{28}$ but rather call for raised awareness, proactive measures, and multifaceted integrated interventions to protect everyone, from our dear ones, to our patients and ourselves.

\section{References}

1. Fauci AS, Lane HC, Redfield RR. Covid-19 - Navigating the Uncharted. N Engl J Med 2020;382:1268-9.

2. Day M. Covid-19: surge in cases in Italy and South Korea makes pandemic look more likely. BMJ 2020;368:m751.

3. Peckham R. COVID-19 and the anti-lessons of history. Lancet 2020;395:850-2.

4. Del Rio C, Malani PN. COVID-19-New Insights on a Rapidly Changing Epidemic. JAMA 2020.[Epub ahead of print]

5. Han Q, Lin Q, Jin S, You L. Recent insights into 2019nCoV: a brief but comprehensive review. J Infect 2020.

6. Sohrabi C, Alsafi Z, O'Neill N, Khan M, Kerwan A, AlJabir A, et al. World Health Organization declares global emergency: A review of the 2019 novel coronavirus (COVID-19). Int J Surg 2020;76:71-6.

7. Società Italiana di Anestesia Analgesia Rianimazione e Terapia Intensiva (SIAARTI) - Raccomandazioni di etica clinica per l'ammissione a trattamenti intensivi e per la loro sospensione, in condizioni eccezionali di squilibrio tra necessità e risorse disponibili; [Internet] Available from: http://www. siaarti.it/News/COVID19\%20-\%20documenti\%20SIAARTI. aspx [cited 2020, Mar 8].

8. American College of Cardiology (ACC) Clinical Bulletin - COVID-19 Clinical GuidanceFor the CVCare Team. [Internet] Available from: https://www.acc.org// /media/NonClinical/Files-PDFs-Excel-MS-Word-etc/2020/02/S20028ACC-Clinical-Bulletin-Coronavirus.pdf [cited 2020, Mar 8].

9. Saglietto A, D'Ascenzo F, Zoccai GB, De Ferrari GM. COVID-19 in Europe: the Italian lesson. Lancet 2020;395:1110-1.

10. Patlas MN. COVID-19: What Can We Learn From Stories From the Trenches? Can Assoc Radiol J 2020:846537120913497.

11. Lipsitch M, Swerdlow DL, Finelli L. Defining the Epidemiology of Covid-19 - Studies Needed. N Engl J Med 2020;382:1194-6.

12. Gurwitz D. Angiotensin receptor blockers as tentative SARS-CoV-2 therapeutics. Drug Dev Res 2020. [Epub ahead of print]

13. Hoffmann M, Kleine-Weber H, Schroeder S, Krüger N, Herrler T, Erichsen S, et al. SARS-CoV-2 Cell Entry Depends on ACE2 and TMPRSS2 and Is Blocked by a Clinically Proven Protease Inhibitor. Cell 2020;S0092-8674(20)30229-4.

14. Wu Z, McGoogan JM. Characteristics of and Important Lessons From the Coronavirus Disease 2019 (COVID-19) Outbreak in China: Summary of a Report of 72314 Cases
From the Chinese Center for Disease Control and Prevention. JAMA 2020. [Epub ahead of print]

15. Ong SW, Tan YK, Chia PY, Lee TH, Ng OT, Wong MS, et al. Air, Surface Environmental, and Personal Protective Equipment Contamination by Severe Acute Respiratory Syndrome Coronavirus 2 (SARS-CoV-2) From a Symptomatic Patient. JAMA 2020. [Epub ahead of print]

16. Li Q, Guan X, Wu P, Wang X, Zhou L, Tong Y, et al. Early Transmission Dynamics in Wuhan, China, of Novel Coronavirus-Infected Pneumonia. N Engl J Med 2020;382:1199-207.

17. Huang C, Wang Y, Li X, Ren L, Zhao J, Hu Y, et al. Clinical features of patients infected with 2019 novel coronavirus in Wuhan, China. Lancet 2020;395:497-506.

18. Ai T, Yang Z, Hou H, Zhan C, Chen C, Lv W, et al. Correlation of Chest CT and RT-PCR Testing in Coronavirus Disease 2019 (COVID-19) in China: A Report of 1014 Cases. Radiology 2020;200642.

19. Young BE, Ong SW, Kalimuddin S, Low JG, Tan SY, Loh J, et al.; Singapore 2019 Novel Coronavirus Outbreak Research Team. Epidemiologic Features and Clinical Course of Patients Infected With SARS-CoV-2 in Singapore. JAMA 2020. [Epub ahead of print]

20. Guan WJ, Ni ZY, Hu Y, Liang WH, Ou CQ, He JX, et al. China Medical Treatment Expert Group for Covid-19. Clinical Characteristics of Coronavirus Disease 2019 in China. N Engl J Med 2020. [Epub ahead of print]

21. Ruan Q, Yang K, Wang W, Jiang L, Song J. Clinical predictors of mortality due to COVID-19 based on an analysis of data of 150 patients from Wuhan, China. Intensive Care Med 2020. [Epub ahead of print]

22. quotidianosanità.it: Coronavirus. Iss: "Febbre e affanno sintomi iniziali più comuni per i deceduti positivi al virus"; [Internet] Available from: http://www.quotidianosanita.it/scienza-e-farmaci/articolo.php?articolo_id $=82255 \& \mathrm{fr}=\mathrm{n} \quad$ [cited 2020, Mar 9].

23. Colson P, Rolain JM, Lagier JC, Brouqui P, Raoult D. Chloroquine and hydroxychloroquine as available weapons to fight COVID-19. Int J Antimicrob Agents 2020 Apr;55(4):105932.

24. Chen L, Xiong J, Bao L, Shi Y. Convalescent plasma as a potential therapy for COVID-19. Lancet Infect Dis 2020;20:398-400.

25. Stebbing J, Phelan A, Griffin I, Tucker C, Oechsle O, Smith D, et al. COVID-19: combining antiviral and anti-inflammatory treatments. Lancet Infect Dis 2020;20:400-2.

26. Zheng YY, Ma YT, Zhang JY, Xie X. COVID-19 and the cardiovascular system. Nat Rev Cardiol 2020. [Epub ahead of print]

27. Gostin LO, Hodge JG Jr. US Emergency Legal Responses to Novel Coronavirus: Balancing Public Health and Civil Liberties. JAMA 2020. [Epub ahead of print]

28. LiberoQuotidiano.it. Coronavirus, Ricciardi: "Può espandersi senza resistenze". I modelli: possibile 1 milione di morti in Italia; [Internet] Available from: https://www. liberoquotidiano.it/news/italia/20895016/coronavirus_ricciardi modelli_italia 60 per cento_contagiato_1_milione morti.html [cited 2020, Mar 9].

Conflicts of interest.-The authors certify that there is no conflict of interest with any financial organization regarding the material discussed in the manuscript.

History.-Article first published online: March 9, 2020. - Manuscript accepted: March 9, 2020. - Manuscript received: March 9, 2020.

(Cite this article as: Biondi Zoccai G, Landoni G, Carnevale R, Cavarretta E, Sciarretta R, Frati G. SARS-CoV-2 amd COVID-19: facing the pandemic together as citizens and cardiovascular practitioners. Minerva Cardioangiol 2020;68:61-4. DOI: 10.23736/ S0026-4725.20.05250-0) 